\title{
In Vitro Evaluation of the Susceptibility of Endodontic Pathogens to Calcium Hydroxide Combined with Different Vehicles
}

\author{
Morgana Eli VIANNA \\ Brenda Paula Figueiredo de Almeida GOMES \\ Neylla Teixeira SENA \\ Alexandre Augusto ZAIA \\ Caio Cezar Randi FERRAZ \\ Francisco José de SOUZA FILHO \\ Department of Restorative Dentistry, Area of Endodontics, Faculty of Dentistry of Piracicaba, \\ State University of Campinas (UNICAMP), Piracicaba, SP, Brazil
}

\begin{abstract}
The aim of this study was to investigate in vitro the antimicrobial activity of calcium hydroxide $\left[\mathrm{Ca}(\mathrm{OH})_{2}\right]$ in combination with different vehicles against endodontic pathogens. For such purpose, a broth dilution test was performed. Pastes were prepared with $\mathrm{Ca}(\mathrm{OH})_{2}$ powder and the following vehicles: sterile water, glycerin, camphorated monochlorophenol $(\mathrm{CMCP}), \mathrm{CMCP}+\mathrm{glycerin}$, polyethyleneglycol and $\mathrm{CMCP}+$ polyethyleneglycol. The time required for the pastes to produce negative cultures against the tested microorganisms was recorded and analyzed statistically using the Kruskal Wallis test at 5\% significance level. Timing for pastes to eliminate the aerobic and facultative anaerobic microorganisms ranged from 6 to $24 \mathrm{~h}$, while strict anaerobic microorganisms were inhibited within $30 \mathrm{~s}$ to $5 \mathrm{~min}$. Microbial susceptibility, ranked from weakest to strongest, can be presented as follows: Enterococcus faecalis (the most resistant microorganism), Candida albicans, Staphylococcus aureus, Porphyromonas gingivalis, Porphyromonas endodontalis and Prevotella intermedia (the last two microorganisms required the same time to be eliminated). In conclusion, calcium hydroxide pastes needed more time to eliminate facultative than anaereobic microorganisms. These findings suggest that the antimicrobial property is related both to paste formulation and to microbial susceptibility.
\end{abstract}

Key Words: Endodontics, intracanal medication, calcium hydroxide, bacteria.

\section{INTRODUCTION}

One of the main goals of root canal treatment is to eliminate bacteria and their by-products before filling. Although dentists try to clean and irrigate the root canal system properly, some bacteria still remain entrapped in the dentinal tubules. It has been shown that, if the canal is not dressed with a disinfectant between two visits, microorganisms will multiply rapidly within days to near the original numbers (1).

Calcium hydroxide $\left[\mathrm{Ca}(\mathrm{OH})_{2}\right]$ has been widely used in Endodontics as an intracanal medicament. It is considered to possess many of the properties of an ideal root canal dressing, acting as a physical barrier, preventing root canal re-infection and interrupting the nutrient supply to the remaining bacteria (2). However, its mechanisms of cell damage are still not well known. The most accepted explanation for $\mathrm{Ca}(\mathrm{OH})_{2}$ antimicrobial mechanism is its high $\mathrm{pH}$. The release of hydroxyl ions in an aqueous environment causes damage to the bacterial cytoplasmic membrane and disrupts both protein denaturation and DNA of bacterial cells (1). The antimicrobial action of calcium hydroxide is also related to its capacity to react with carbon dioxide in the root canal (4) and thus some $\mathrm{CO}_{2}$-dependent bacteria do not survive in this environment.

Correspondence: Profa. Dra. Brenda P. F. A. Gomes, Departamento de Odontologia Restauradora, Endodontia, Faculdade de Odontologia de Piracicaba, UNICAMP, Av. Limeira, 901, 13414-903 Piracicaba, SP, Brasil. Tel: +55-19-3412-5215. Fax: +55-19-3412-5218. e-mail: bpgomes@fop.unicamp.br 
The use of intracanal medication disturbs the established nutritional interrelationships. It eliminates some bacteria that may be essential to the growth of other microorganisms or, in opposite, leaves behind bacteria that prevent the growth of other pathogens (5). However, for calcium hydroxide to exert its antimicrobial activity, directly or indirectly, an ideal timing is required for effective destruction of microorganisms (3).

The classification and clinical indications of various formulations of $\mathrm{Ca}(\mathrm{OH})_{2}$ and their mechanisms of antimicrobial action have been reviewed (2,6). Although calcium hydroxide has been used for over 80 years, there are still many questions to be answered regarding its inhibitory activity against pathogens.

This in vitro study evaluated the susceptibility of some microorganisms (five bacteria and one yeast) commonly isolated from infected root canals to calcium hydroxide in combination with different vehicles, and assessed the time required for elimination of these pathogens using the direct contact method.

\section{MATERIAL AND METHODS}

The methodology of this study was adapted from Gomes et al. (7), who used a broth dilution test to quantify the time required for an antimicrobial agent to inhibit microbial growth.

The microbial strains were evaluated against calcium hydroxide pastes prepared with calcium hydroxide powder (Labsynth Produtos para Laboratórios Ltda, São Paulo, SP, Brazil) mixed with different vehicles, as follows: sterile water (2:1), glycerin $(2: 1$; Chemco Ind. e Com. Ltda, Campinas, SP, Brazil), camphorated paramonochlorophenol (CMCP) (2:1; Biodinâmica, Química e Farmacêutica Ltda., Ibiporã, PR, Brazil), CMCP plus glycerin (Frank's paste; 2:1:1), polyethyleneglycol 400 (2:1; Quimimax Comércio e Indústria Ltda, Campinas, SP, Brazil) and $\mathrm{CMCP}$ plus polyethyleneglycol $400(2: 1: 1)$. The consistency of the pastes was similar to that of toothpaste, with a viscosity of $3501 \mathrm{cP}$ at $0.1 \mathrm{rpm}$ (Brookfield Digital Reometer, model DV-III-IV, São Paulo, SP, Brazil). The $\mathrm{pH}$ of the pastes ranged from 12.5 to 13 , as measured with a $\mathrm{pH}$ meter (DIGIMED DM 21 V7c, São Paulo, SP, Brazil).

Controls were sterile water, $0.89 \%$ sterile saline, glycerin, polyethyleneglycol, CMCP, CMCP plus polyethyleneglycol and CMCP plus glycerin.

The following microbial strains were used in this study: Candida albicans NTCC 3736 (yeast) [grown on agar sabouraud dextrose plates (Oxoid, Basingstoke, Hampshire, UK) for $48 \mathrm{~h}$ at $37^{\circ} \mathrm{O}_{2}$ ]; Enterococcus faecalis ATCC 29212 (grown on 5\% sheep blood-Brain Heart Infusion (BHI) agar plates for $48 \mathrm{~h}$ at $37^{\circ} \mathrm{CO}_{2}$ ); Staphylococcus aureus ATCC 25923 (grown on 5\% sheep blood-BHI agar plates for $48 \mathrm{~h}$ at $37^{\circ} \mathrm{O}_{2}$ ); Porphyromonas gingivalis, Porphyromonas endodontalis and Prevotella intermedia. All species were isolated from infected root canals and identified using conventional biochemical tests. The last 3 pathogens (strict anaerobic microorganisms) were previously subcultured on 5\% sheep blood Fastidious Anaerobe Agar (FAA, Lab M, Bury, UK) plates for $48 \mathrm{~h}$ in anaerobic gaseous conditions $\left(10 \% \mathrm{CO}_{2}, 10 \% \mathrm{H}_{2}\right.$ and $80 \% \mathrm{~N}_{2}$ ) at $37^{\circ} \mathrm{C}$. The microbial concentrations used were according to Koo et al. (8), with optic density (OD) at $800 \mathrm{~nm}$ suspension determined spectrophotometrically.

The aerobic strains (C. albicans and S. aureus) and the facultative strain (E. faecalis) were individually inoculated into tubes containing $5 \mathrm{~mL}$ BHI sterile suspension, which were adjusted at $800 \mathrm{~nm}\left(\mathrm{OD}_{800}\right)$ to match the turbidity of $1.5 \times 10^{8}$ colony forming units (cfu) $\mathrm{mL}^{-1}$ (equivalent to $0.5 \mathrm{McFarland}$ standard). The strict anaerobic microorganisms were individually inoculated into tubes containing $5 \mathrm{~mL}$ of Fastidious Anaerobe Broth (FAB, Lab M, Bury, UK) sterile suspension, which were suspended at $800 \mathrm{~nm}\left(\mathrm{OD}_{800}\right)$ to match the turbidity of $3.0 \times 10^{8} \mathrm{cfu} \mathrm{mL}^{-1}$ (equivalent to $1 \mathrm{McF}$ arland standard).

Six wells were used for each time, microorganism and calcium hydroxide paste. A total of 6,912 wells were used, comprising 2,880 wells for the tested pastes and 4,032 for control groups ( 576 for each medicament or each control). One $\mathrm{mL}$ of each test medicament and control was placed in 24-well cell culture plates (ref. No. 3524, well vol. $3.2 \mathrm{~mL}$; Corning, NY, USA). Two $\mathrm{mL}$ of the microbial suspension were added to $\mathrm{Ca}(\mathrm{OH})_{2}$ pastes and controls.

The well cell culture plates were placed onto an upside down $250 \mathrm{~mL}$ stainless steel griffin beaker (BK 1122, MGL Scientific, Elko, NV, USA) inside an ultrasonic cleaner (Bransonic Ultrasonics Corporation, Danbury, CT, USA) that had been previously filled with $1400 \mathrm{~mL}$ of distilled water up to the operating level. These plates were ultrasonicated for $10 \mathrm{~s}$ and left to stand different periods of time, viz. for 15 and $30 \mathrm{~s} ; 1$, 
3, 5, 10, 15 and $30 \mathrm{~min} ; 1,2,4,6,8,12,24$ and $48 \mathrm{~h}$; and for 7 days.

After each period of time, $1 \mathrm{~mL}$ from each well was transferred to tubes containing $3 \mathrm{~mL}$ of freshly broth media (BHI for aerobes and facultative strains; FAB for strict anaerobic microorganisms), which had $0.5 \%$ citric acid to prevent continued action of the calcium hydroxide. All tubes were stored at $37^{\circ} \mathrm{C}$ for 7 days in appropriate gaseous conditions (aerobic microorganism and yeast at $\mathrm{O}_{2}$, facultative microorganism at $\mathrm{CO}_{2}$ and strict anaerobic microorganisms at $10 \% \mathrm{CO}_{2}, 10 \% \mathrm{H}_{2}$ and $80 \% \mathrm{~N}_{2}$ ) for microbial growth. Thereafter, $10 \mu \mathrm{L}$ of each tube was inoculated on agar plates and left at $37^{\circ} \mathrm{C}$ for 24 to 48 days in appropriate gaseous conditions to investigate all possible microbial growth.

The purity of the positive cultures was confirmed by Gram staining, colony morphology on blood agar plates and use of biochemical identification kits Rapid ID 32 Strep, APIC AUX and API 20 Staph (BioMérieux SA, Marcy-l'Etoile, France) and the RapID ANA II System (Remel Inc., Lenexa, KS, USA). Miniapi software (BioMérieux SA) was used to automatically read ID 32 tests and visually-read API range tests from BioMérieux.

The time required for each medicament to produce total microbial inhibition growth was recorded and converted into hours, minutes and seconds. Data were analyzed statistically by Kruskal-Wallis test at 5\% significance level (Biostat program, CNPq, 2000, Brazil).

\section{RESULTS}

Table 1 shows the contact time required for calcium hydroxide pastes to produce negative cultures (i.e., $100 \%$ growth inhibition) against the tested microorganisms.

All $\mathrm{Ca}(\mathrm{OH})_{2}$ pastes were able to eliminate $P$. endodontalis and P. intermedia within $30 \mathrm{~s}$, and no statistically significant differences were found among the medicaments $(\mathrm{p}>0.05)$. P. gingivalis was a little more resistant, being killed from $30 \mathrm{~s}$ to $5 \mathrm{~min}$. Pastes prepared with $\mathrm{CMCP}$ and $\mathrm{CMCP}$ plus glycerin took the shortest time to eliminate $C$. albicans ( $6 \mathrm{~h}$ on average). $\mathrm{Ca}(\mathrm{OH})_{2}$ pastes prepared with $\mathrm{CMCP}$ were more effective to eliminate $E$. faecalis, taking $6 \mathrm{~h}$ on average to produce negative cultures, while $\mathrm{CMCP}+$ glycerin paste needed $12 \mathrm{~h}$ and the other pastes took $24 \mathrm{~h}$.

The pastes prepared with viscous vehicles alone (glycerin and polyethyleneglycol) had the same performance against $S$. aureus $(12 \mathrm{~h})$, while $\mathrm{Ca}(\mathrm{OH})_{2}+$ $\mathrm{CMCP}$ required $4 \mathrm{~h}$ and $\mathrm{Ca}(\mathrm{OH})_{2}+\mathrm{CMCP}+$ glycerin or polyethyleneglycol needed $8 \mathrm{~h}$ to eliminate the same microorganism.

Overall, pastes prepared with CMCP took less time to kill the tested microorganisms than those prepared

Table 1. Contact time (in hours, minutes, seconds) required by the calcium hydroxide pastes prepared with different vehicles to produce negative cultures (i.e., $100 \%$ inhibition growth) against the target microorganisms.

\begin{tabular}{|c|c|c|c|c|c|c|c|}
\hline \multirow[t]{2}{*}{$\mathrm{Ca}(\mathrm{OH})_{2}$ pastes } & \multicolumn{7}{|c|}{ Microorganisms } \\
\hline & $\begin{array}{c}\text { S. } \\
\text { aureus }\end{array}$ & $\begin{array}{c}\text { E. } \\
\text { faecalis }\end{array}$ & $\begin{array}{c}\text { C. } \\
\text { albicans }\end{array}$ & $\begin{array}{c}P . \\
\text { endodontalis }\end{array}$ & $\begin{array}{c}P . \\
\text { gingivalis }\end{array}$ & $\begin{array}{c}P . \\
\text { intermedia }\end{array}$ & $\begin{array}{c}\text { Maximum } \\
\text { time/paste* }\end{array}$ \\
\hline Sterile water & $8 \mathrm{~h}$ & $24 \mathrm{~h}$ & $24 \mathrm{~h}$ & $30 \mathrm{~s}$ & $30 \mathrm{~s}$ & $30 \mathrm{~s}$ & $24 \mathrm{~h}(\mathrm{a})$ \\
\hline Glycerin & $12 \mathrm{~h}$ & $24 \mathrm{~h}$ & $24 \mathrm{~h}$ & $30 \mathrm{~s}$ & $5 \mathrm{~min}$ & $30 \mathrm{~s}$ & $24 \mathrm{~h}(\mathrm{a})$ \\
\hline Sterile water & $8 \mathrm{~h}$ & $24 \mathrm{~h}$ & $24 \mathrm{~h}$ & $30 \mathrm{~s}$ & $30 \mathrm{~s}$ & $30 \mathrm{~s}$ & $24 \mathrm{~h}(\mathrm{a})$ \\
\hline Glycerin & $12 \mathrm{~h}$ & $24 \mathrm{~h}$ & $24 \mathrm{~h}$ & $30 \mathrm{~s}$ & $5 \mathrm{~min}$ & $30 \mathrm{~s}$ & $24 \mathrm{~h}(\mathrm{a})$ \\
\hline $\mathrm{CMCP}$ & $6 \mathrm{~h}$ & $6 \mathrm{~h}$ & $4 \mathrm{~h}$ & $30 \mathrm{~s}$ & $30 \mathrm{~s}$ & $30 \mathrm{~s}$ & $6 \mathrm{~h}(\mathrm{a})$ \\
\hline $\mathrm{CMCP}+$ Glycerin & $8 \mathrm{~h}$ & $12 \mathrm{~h}$ & $6 \mathrm{~h}$ & $30 \mathrm{~s}$ & $1 \mathrm{~min}$ & $30 \mathrm{~s}$ & $12 \mathrm{~h}(\mathrm{a})$ \\
\hline $\mathrm{CMCP}+$ polyethyleneglycol & $8 \mathrm{~h}$ & $24 \mathrm{~h}$ & $8 \mathrm{~h}$ & $30 \mathrm{~s}$ & $3 \mathrm{~min}$ & $30 \mathrm{~s}$ & $24 \mathrm{~h}(\mathrm{a})$ \\
\hline Polyethyleneglycol & $12 \mathrm{~h}$ & $24 \mathrm{~h}$ & $24 \mathrm{~h}$ & $30 \mathrm{~s}$ & $5 \mathrm{~min}$ & $30 \mathrm{~s}$ & $24 \mathrm{~h}(\mathrm{a})$ \\
\hline Maximum time/all pastes** & $12 \mathrm{~h}(\mathrm{AB})$ & $24 \mathrm{~h}(\mathrm{~A})$ & $24 \mathrm{~h}(\mathrm{~A})$ & $30 \mathrm{~s}(\mathrm{~B})$ & $5 \min (\mathrm{B})$ & $30 \mathrm{~s}(\mathrm{~B})$ & \\
\hline
\end{tabular}

*Maximum time required by each paste to produce negative cultures. ${ }^{*}$ Maximum time required by all pastes to produce negative cultures against each microorganism. Different letters indicate statistically significant difference $(\mathrm{p}<0.05)$. CMCP $=$ camphorated paramonochlorophenol. 
with viscous (glycerin and polyethyleneglycol) and aqueous (sterile water) vehicles alone (Fig. 1). Aerobic and facultative anaerobic microorganisms were more resistant to $\mathrm{Ca}(\mathrm{OH})_{2}$ and the time required for their elimination ranged from 4 to $24 \mathrm{~h}$. On the other hand, strict anaerobic microorganisms were eliminated within 5 min or less.

Microbial susceptibility, ranked from the most resistant to the most suscetible microoganism, can be presented as follows: E. faecalis, C. albicans, S. aureus, $P$. gingivalis, $P$. endodontalis and $P$. intermedia (Table 1 and Fig. 2).

$\mathrm{CMCP}, \mathrm{CMCP}$ plus glycerin, and CMCP plus polyethyleneglycol controls produced negative cultures against all tested microorganisms within $30 \mathrm{~s}$. Sterile water, saline, glycerin and polyethyleneglycol did not produce negative cultures (Table 2).

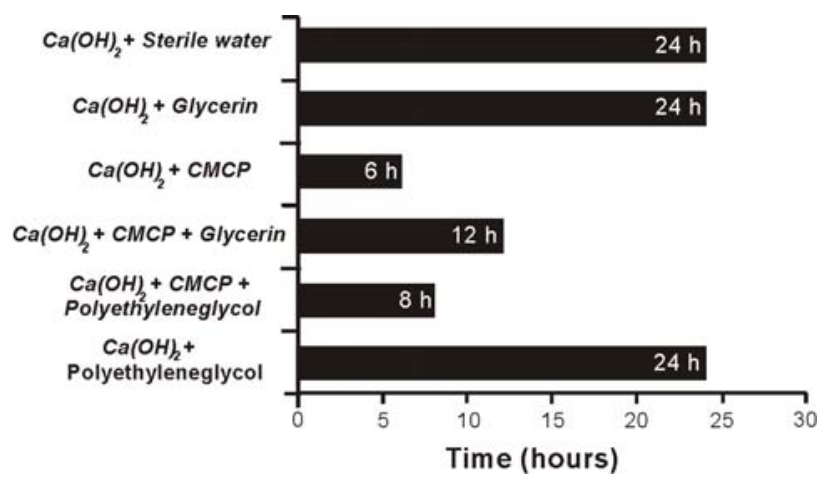

Figure 1. Maximum time required by each medicament to inhibit microbial growth $\mathrm{CMCP}=$ camphorated paramonochlorophenol.

\section{DISCUSSION}

The type of vehicle used to prepare calcium hydroxide pastes produces differences in the velocity of ionic dissociation (9). Depending on the vehicle used, the medicament can have a different viscosity, which is a measurement of the inner friction of a fluid. A solution flows easier when its viscosity is low.

Paste is considered chemically to be a colloid (a solid dispersed into a liquid). Therefore, the type of vehicle used may facilitate or inhibit the ionic dispersion from the paste, i.e., the lower the viscosity, the higher the ionic dissociation and the antimicrobial activity (6).

Calcium hydroxide has been associated with several substances, such as saline, camphorated monochlorophenol, antibiotics, chlorhexidine, sodium lauryl sulfate, among others (9). Vehicles are commonly

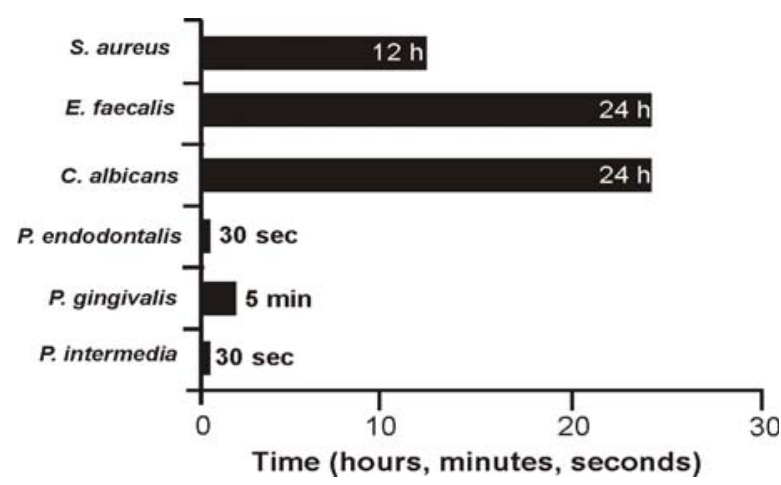

Figure 2. Maximum time required by each microorganism to be killed by the tested medicaments.

Table 2. Contact time (in seconds) required by the control groups to produce negative cultures (i.e., 100\% inhibition growth) against the target microorganisms.

\begin{tabular}{|c|c|c|c|c|c|c|}
\hline \multirow[t]{2}{*}{ Controls } & \multicolumn{6}{|c|}{ Microorganisms } \\
\hline & $\begin{array}{c}\text { S. } \\
\text { aureus }\end{array}$ & $\begin{array}{c}E . \\
\text { faecalis }\end{array}$ & $\begin{array}{c}\text { C. } \\
\text { albicans }\end{array}$ & $\begin{array}{c}P . \\
\text { endodontalis }\end{array}$ & $\begin{array}{c}P . \\
\text { gingivalis }\end{array}$ & $\begin{array}{c}P . \\
\text { intermedia }\end{array}$ \\
\hline Sterile water & - & - & - & - & - & - \\
\hline $0.89 \%$ saline & - & - & - & - & - & - \\
\hline \multicolumn{7}{|l|}{ Glycerin } \\
\hline CMCP + Glycerin & $30 \mathrm{~s}$ & $30 \mathrm{~s}$ & $30 \mathrm{~s}$ & $30 \mathrm{~s}$ & $30 \mathrm{~s}$ & $30 \mathrm{~s}$ \\
\hline Polyethyleneglycol & - & - & - & - & - & - \\
\hline CMCP + Polyethyleneglycol & $30 \mathrm{~s}$ & $30 \mathrm{~s}$ & $30 \mathrm{~s}$ & $30 \mathrm{~s}$ & $30 \mathrm{~s}$ & $30 \mathrm{~s}$ \\
\hline
\end{tabular}

$\mathrm{CMCP}=$ camphorated paramonochlorophenol. 
classified as aqueous, viscous or oily (6). Aqueous vehicle rapidly dissociates calcium hydroxide in $\mathrm{Ca}^{++}$ and $\mathrm{OH}^{-}$, promoting high solubility when in contact with fluids and being easily reabsorbed by macrophages (3). Some viscous vehicles, such as glycerin and propyleneglycol, are also water-soluble, but dissociate more slowly, probably because of their molecular weight. Oily vehicles are non-water-soluble substances that promote the lowest solubility and diffusion of the paste within the tissues (6).

In this study, pastes prepared with a combination of a vehicle (sterile water, glycerin, polyethyleneglycol) and the therapeutic adjunct (CMCP) were more effective against the target pathogens, although their action occurred within different times. Pastes prepared with glycerin and polyethyleneglycol needed more time to eliminate the microorganisms than the other pastes. These findings are in agreement with those of Safavi and Nakayama (10), who reported that high concentrations of glycerin and propyleneglycol used as vehicles might decrease the effectiveness of calcium hydroxide, slowing the release of hydroxyl ions.

The CMCP-containing pastes showed the best antimicrobial activity, which may probably be attributed to CMCP strong antimicrobial properties. The camphor in CMCP is an essential oil with low solubility in water, allowing a slow release of calcium hydroxide ions from the pastes (6). Using a similar methodology, Siqueira and Uzeda (11) also reported better in vitro antimicrobial activity of calcium hydroxide combined with CMCP and glycerin. Gomes et al. (5) had similar results using a different methodology (agar diffusion method).

The findings of the present study showed that $\mathrm{CMCP}$ alone was a potent antimicrobial agent, killing the microorganisms in less than $1 \mathrm{~min}$. However, it is a phenolic compound with a cytotoxic action when in contact with periapical tissues $(14,15)$. This fact was also discussed by Block et al. (16), who reported that CMCP altered dogs' pulp tissue, rendered it antigenically active and produced a specific humoral response. In addition, $\mathrm{CMCP}$ has been shown to become ineffective in the root canal within 24-48 $\mathrm{h}(12,13)$. Another fact that does not recommend the use of CMCP as intracanal medicament is that it does not act as a physicochemical barrier. Such a barrier is important for preventing root canal recontamination due to growth of bacteria that are not removed during biomechanical preparation or to saliva and microorganism infiltration caused by coronal microleakage (12). CMCP does not act as a physical barrier because it is commonly applied on sterile cotton pledgets placed in the pulp chamber or on paper points slightly moistened with this medicament. In both cases, the medication is left in the root canals between sessions.

The results of this study showed that the combination of $\mathrm{Ca}(\mathrm{OH})_{2}$ and $\mathrm{CMCP}$ had a wider antimicrobial spectrum of activity, which agrees with the findings of previous studies $(5,11)$. However, this association strongly inhibited the antimicrobial potential of CMCP alone, especially against the aerobic and facultative anaerobic pathogens. This can be attributed to the formation of calcium PMC, which is a weak salt (6). It has been shown that the use of CMCP alone or in combination with $\mathrm{Ca}(\mathrm{OH})_{2}$ is not recommended, mainly due to its potential to cause tissue irritation (17).

The microbial strains used in this experiment were selected from those that are most commonly associated with endodontic symptomatology, such as the Gram-negative anaerobes, and those that are most often associated with root canal failures, such as $E$. faecalis and C. albicans (18). Aerobes and facultative microorganisms were more resistant to the tested intracanal medicaments than strict anaerobes, which is consistent with previous findings (5).

Most investigations on $\mathrm{Ca}(\mathrm{OH})_{2}$ antimicrobial activity have used the agar diffusion method, which only indicates the medicament potential to eliminate bacteria within the root canal system (5), but does not quantify its action timing. In the present study, the direct contact method was used, which relies on direct and close contact between the test microorganism and materials (19). It is considered a more precise method to analyze medications than the agar diffusion (20), in which the medicaments dissociate and diffuse differently through the media. In summary, the direct contact method uses a liquid culture medium and allows liquid and paste formulations to have a more similar diffusion conditions than the agar diffusion method.

Although the method used is more reliable than the agar diffusion test, it also has limitations: a) clinically, the effectiveness of the material is reduced by dentin buffering effect; $b$ ) the amount of intracanal medication is usually smaller than that used in in vitro studies; c) the polymicrobial nature of endodontic infections is difficult to be reproduced in vitro; d) the presence of biofilms might require more time and volume of medicament to exert the same antimicrobial activity. 
Despite the limitations of in vitro experiments, it was possible to compare the antimicrobial activity and the time required by several intracanal medicaments to eliminate endodontic pathogens. All calcium hydroxide pastes showed antimicrobial action but at different times. According to the methodology proposed and based on the results of this study, it may be concluded that calcium hydroxide pastes needed more time to eliminate facultative than anaereobic microorganisms. Moreover, the time required for the pastes to eliminate the endodontic pathogens depended on both the paste formulation and the microbial susceptibility.

\section{RESUMO}

O objetivo deste estudo foi avaliar in vitro a atividade antimicrobiana do hidróxido de cálcio $[\mathrm{Ca}(\mathrm{OH}) 2]$ em associação com diferentes veículos frente a patógenos endodônticos. $\mathrm{O}$ teste de difusão em caldo foi utilizado. Foram preparadas pastas com pó de $\mathrm{Ca}(\mathrm{OH})_{2}$ e os seguintes veículos: água destilada, glicerina, PMCC (paramonoclorofenol canforado), PMCC + glicerina, e PMCC + polietilenoglicol. O tempo necessário para as pastas produzirem culturas negativas frente aos microorganismos testados foi registrado e analisado estatisticamente por meio do teste de Kruskal Wallis com nível de significância de $5 \%$. Foram necessárias de 6 a 24 h para eliminar os microrganismos aeróbios e facultativos e de $30 \mathrm{~s}$ a $5 \mathrm{~min}$ para os anaeróbios estritos. A suscetibilidade microbiana em ordem crescente foi: Enterococcus faecalis (patógeno mais resistente), Candida albicans, Staphylococcus aureus, Porphyromonas gingivalis, Porphyromonas endodontalis e Prevotella intermedia (os últimos dois microrganismos necessitaram do mesmo tempo para serem eliminados). Concluiuse que as pastas de hidróxido de cálcio necessitaram de maior tempo para eliminar os microrganismos facultativos do que os anaeróbios. Esses achados sugerem que a propriedade antimicrobiana está relacionada tanto à formulação da pasta quanto à suscetibilidade microbiana.

\section{ACKNOWLEDGEMENTS}

We would like to thank Mr. Adailton dos Santos Lima for technical assistance and Biolab Mérieux for lending the MiniApi equipment. This study was supported by a grant-in-aid from the Brazilian agencies FAPESP (00/13689-7), CNPq and CAPES.

\section{REFERENCES}

1. Byström A, Claesson R, Sundqvist G. The antibacterial effect of camphorated paramonochlorophenol, camphorated phenol and calcium hydroxide in the treatment of infected root canals. Endod Dent Traumatol 1985;1:170-175.

2. Siqueira JF Jr, Lopes HP. Mechanisms of antimicrobial activity of calcium hydroxide: a critical review. Int Endod J 1999;32:361-369.

3. Estrela C, Pimenta FC, Ito IY, Bammann LL. In vitro determination of direct antimicrobial effect of calcium hydroxide. J Endod 1998;24:15-17.

4. Kontakiotis E, Nakou M, Georgopoulou M. In vitro study of the indirect action of calcium hydroxide on the anaerobic flora of the root canal. Int Endod J 1995;28:285-289.

5. Gomes BP, Ferraz CC, Vianna ME, Rosalen PL, Zaia AA, Teixeira FB, Souza-Filho FJ. In vitro antimicrobial activity of calcium hydroxide pastes and their vehicles against selected microorganisms. Braz Dent J 2002;13:155-161.

6. Fava LRG, Saunders WP. Calcium hydroxide pastes classification and clinical indications. Int Endod $\mathrm{J}$ 1999;32:257-282.

7. Gomes BPFA, Ferraz CCR, Vianna ME, Berber VB, Teixeira $\mathrm{FB}$, Souza-Filho FJ. In vitro antimicrobial activity of several concentrations of sodium hypochlorite and chlorhexidine gluconate in the elimination of Enterococcus faecalis. Int Endod J 2001;34:424-428.

8. Koo H, Gomes BPFA, Rosalen PL, Ambrosano GMB, Park YK, Cury JA. In vitro antimicrobial activity of propolis and Arnica montana against oral pathogens. Arch Oral Biol 1999;45:141-148.

9. Estrela C, Bammann LL, Pimenta FC, Pécora JD. Control of microorganisms in vitro by calcium hydroxide pastes. Int Endod J 2001;34:341-345.

10. Safavi K, Nakayama TA. Influence of mixing vehicle on dissociation of calcium hydroxide in solution. J Endod 2000;26:649-651.

11. Siqueira JF Jr, Uzeda M. Influence of different vehicles on the antibacterial effects of calcium hydroxide. J Endod 1998;24:663-665.

12. Koontongkaew S, Silapichit R, Thaweboon B. Clinical and laboratory assessments of camphorated monochlorophenol in endodontic therapy. Oral Surg Oral Med Oral Pathol 1988;65:757-762.

13. Messer HH, Chen RS. The duration of effectiveness of root canal medicaments. J Endod 1984;10:240-245.

14. Holland R, Souza V, Nery MJ, Otoboni Filho JA, Bernabe PFE. Reaction of rat connective tissue to implanted dentin tubes filled with mineral trioxide aggregate or calcium hydroxide. J Endod 1999;254:161-166.

15. Chang YC, Tai KW, Chou LS, Chou MY. Effects of camphorated parachlorophenol on human periodontal ligament cells in vitro. J Endod 1999;25:779-781.

16. Block RM, Lewis RD, Sheats JB, Burke SH. Antibody formation to dog pulp tissue altered by camphor paramonochlorophenol via the root canal. Oral Surg Oral Med Oral Pathol 1981;51:637-642.

17. Fujii H, Machida Y. Histological study of therapy for infected nonvital permanent teeth with incompletely formed apices. Bull Tokyo Dent Coll 1991;32:35-45.

18. Gomes PBFA, Lilley JD, Drucker DB. Variations in the susceptibilities of components of the endodontic microflora to biomechanical procedures. Int Endod J 1996;29:235-241.

19. Weiss EI, Shalhav M, Fuss Z. Assessment of antibacterial activity of endodontic sealers by a direct contact test. Endod Dent Traumatol 1996;12:179-184.

20. Estrela C, Estrela CRA, Moura J, Bammann LL. Testing calcium hydroxide antimicrobial potential by different methods. J Dent Res 2000;79:529 (Abstract 3081).

Accepted September 19, 2005 